Small plaice of $16 \cdot 5-20 \mathrm{~cm}$ were used at $6 \cdot 5^{\circ} \mathrm{C}$ in 31 . of solution each of $0.0025,0.01,0.025$ and 0.05 per cent propylene phenoxetol. In the two weakest solutions the fish never became completely anæsthetized even after $6 \mathrm{~h}$, though they were considerably quietened. In 0.01 per cent propylene phenoxetol the plaice were limp and did not curl when turned over after $30 \mathrm{~min}$, and even after $6 \mathrm{~h}$ they recovered in $20-30 \mathrm{~min}$, when returned to clean seawater. In the 0.025 per cent solution the plaice were again completely anæsthetized after $30 \mathrm{~min}$, but they were not able to recover after $6 \mathrm{~h}$ in the solution. They took $30 \mathrm{~min}$ to recover their normal activity after $1 \mathrm{~h}$ exposure to the anæsthetic. In the strongest solution, 0.05 per cent, the fish were quite limp, and opercular movements had stopped after $30 \mathrm{~min}$, but within $6 \mathrm{~min}$ of being transferred to clean water they were able to recover, and even after $1 \mathrm{~h}$ in the propylene phenoxetol recovery was possible. After $3 \mathrm{~h}$ in this solution the fish were dead.

The second experiment was carried out with larger fish of 27-33 cm in three strengths of propylene phenoxetol solution at $15^{\circ} \mathrm{C}$. In the weakest solution, 0.005 per cent, the fish took $2 \mathrm{~h}$ to become completely anæsthetized and were unable to recover after $3 \mathrm{~h}$ in it. In 0.01 per cent propylene phenoxetol the plaice were limp after $20 \mathrm{~min}$ and could recover after $2 \mathrm{~h}$ in the solution, but not after $3 \mathrm{~h}$. In the strongest solution. 0.025 per cent, the fish appeared completely anæsthetized after $5 \mathrm{~min}$ and were able to recover after $30 \mathrm{~min}$ in the propylene phenoxetol but not after $1 \mathrm{~h}$.

From the experiments it is concluded that, for anxsthetizing fish for a period of more than $3 \mathrm{~h}$, propylene phenoxetol must be used with great care since the strength of the solution and the temperature are critical. On the other hand, the experiments also show that it is a useful anæsthetic for periods of up to $1 \mathrm{~h}$ when a solution of $0.01-0.025$ per cent can be used at normal laboratory and aquarium temperatures with fish of a wide range in size.

\section{Marine Station.}

T. B. BAGENAL Millport.

${ }^{3}$ Owen, G., and Steedman, H. F., Quart. J. Micro. Sci., 97, 319 (1956).

${ }^{2}$ Owen, G., and Steedman, H. F., Proc. Malar. Soc., London, 33, 3, 101 (1958).

${ }^{3}$ Owen, G., Nature, 175, 434 (1955).

\section{Tubularia crocea L. Agassiz in British Waters}

RECENTLY some colonies of a tubularian hydroid were submitted to the British Museum (Natural History) by Dr. S. Markowski. The colonies were found attached to a rope at the intake of Cliff Quay Power Station, near Ipswich, on the River Orwell in July 1959. In general appearance the colonies resembled $T$. larynx in having a stem height of about $5 \mathrm{~cm}$.

However, careful examination of the ripe female gonophores revealed that instead of the usual four, blunt, rounded tentacular rudiments, the gonophores possessed 6-8 laterally compressed ridges. The species was therefore something unusual for the British fauna and it was identified with Tubularia crocea L. Agassiz', a species of cosmopolitan distribution in warmer waters.

The latter species has previously been reported from British waters - by E. T. Browne ${ }^{2}$, on the stern of a sailing ship in Plymouth Sound. This ship had arrived direct from Iquique, Peru, in September 1895, and it is evident that some colonies survived in Plymouth Sound for some years because two colonies were found in 1907. They were examined by Browne and are briefly recorded ${ }^{3}$. Browne's manuscript notes state that two specimens were found on the bottom of the laboratory boat on October 21, 1907; one of these polyps possessed the eight apical ridges on the female gonophores. Later (October 25), a special search of the buoys in the Sound yielded a large colony with gonophores containing actinulæ. Browne noted that in the hydranth, the hypostome, stomach, collar and the spadix in the gonophores were a deep erimson. From a comparison of $T$. crocea and $T$. larynx side-by-side he noted that whereas the collar and neck of the hydranth were deeply pigmented in the species crocea, it did not, on the other hand, show any conspicuous coloration in that part in T. larynx. Other differences in trophosome indicated by Browne may be summarized as follows:

\section{T. larynx \\ Expanded distal tentacles later- ally compressed with sharp inner edge with inconspicuous
narrow band of nematocysts.} tered nematocysts.
Proximal tentacles with few scat-

\section{T. crocea \\ Expanded distal tentacles with broader nematocyst band.} ered with nematocysts, more or
less arranged in elusters.
Proximal tentacles thickly cov-

A search of the British Museum collections did not reveal any genuine material of $T$. crocea from North American waters but a chance examination of the type material of Tubularia polycarpa Allman ${ }^{4}$, from Coquimbo, Peru, yielded abundant fertile polyps. The gonophores of these, too, possessed the characteristic apical ridges in the female gonophores and in the male gonophores the tentacle rudiments were reduced to a slightly raised ring around the aperture: these characteristics indicate that this species must now be regarded as synonymous with $T$. crocea.

One other species, Tubularia mesembryanthemum Allman, remains to be considered. This was described and figured by Allman from the Gulf of Spezia at the same time that he described $T$. polycarpa. In his diagnosis of $T$. mesem. bryanthemum, Allman mentions that the female gonophore possesses "eight compressed, crest-like apical processes, which are replaced in the male by four small rounded tubercules". In the Ipswich material (but not Browne's Plymouth colonies) male gonophores have been seen. Agassiz declared that in his $T$. crocea there were no tubercules but whether $T$. mesembryanthemum is a distinct species on account of the four small rounded tubercules remains to be elucidated. The species which Bedot ${ }^{5}$ recorded from Roscoff as having "les tubercules et les côtes longitudinales caractéristiques" thus retains the name $T$. mesembryanthemum unless the latter species proves to be identical with $T$. crocea.

It is significant that the occurrence of Tubularia crocea in a new British locality should be in the vicinity of $\mathbf{a}$ power station which uses sea water for cooling purposes.

British Museum (Natural History),

W. J. REES London, S.W.7.

${ }^{2}$ Contrib. Nat. Hist. U.S., 4, 249 (1862).

2 J. Mar. Biol. Assoc. U.K., 5, 54 (1897).

${ }^{3}$ Plymouth Marine Fauna, third ed., 37 (1957).

Allman, G. J., Mon. Gymnobl. Hydr., 413, 418 (1871-72).

‘ Arch. zool. exp. gén., (5), 6, 203 (1911).

\section{Beginning of the Accumulation of Vanadium during the Early Development of the Ascidian Phallusia mamillata Cuvier}

WHEN the uptake of vanadium by the tunicate Phallusia mamillata was investigated, it was observed ${ }^{1}$ that small (young) animals ( $<20 \mathrm{~g}$ fresh weight) accumulated the metal far more intensively than adult ones. This gave rise to the question at which stage of their development the animals become capable of absorbing vanadium. Furthermore, an attempt was made to find out whether this phase coincides with the differentiation of the blood cells, because in Phallusia mamillata the vanadium is present almost exclusively within specific blood cells, that is, vanadocytes.

Unfertilized and fertilized eggs (fertilization rate 80-90 per cent) were incubated in sea-water with an addition of nearly carrier-free vanadate- $\left[{ }^{48} \mathrm{~V}\right]$ at $18^{\circ} \mathrm{C}$ in the dark. The unfertilized eggs contained no more than 5 per cent 